\title{
Comparing Harvest Productivity of the Filamentous Alga Oedogonium with Microalgae
}

\author{
Rebecca O'Connell' ${ }^{1}$, Ann C. Wilkie ${ }^{2}$ \\ ${ }^{1}$ College of Agricultural and Life Sciences, University of Florida \\ ${ }^{2}$ Department of Soil and Water Sciences, University of Florida
}

Faculty mentor: Ann C. Wilkie, Department of Soil and Water Sciences

\begin{abstract}
As the planet faces depletion of its natural resources, alternative and sustainable energy sources are becoming increasingly sought after. Research on the growth of algae has revealed their potential for carbon capture to reduce greenhouse gas emissions and for conversion into a fuel source for bioenergy applications. Filamentous algae have attracted recent attention as an optimal species due to their ease of harvest and dominance over other species. To determine the most suitable species for future biomass applications, a 1000-L open raceway pond was inoculated with the freshwater filamentous alga, Oedogonium, with the addition of $\mathrm{CO}_{2}$. An additional two 1000-L raceway ponds with established cultures of microalgae already receiving $\mathrm{CO}_{2}$ were used as a comparison to the growth of Oedogonium. The pond culture was harvested weekly to determine culture density/growth (mg VSS/L) and harvest productivity (g VSS $/ \mathrm{m}^{2}$-day). After 3 weeks, Oedogonium harvest productivity exceeded both microalgal ponds at $13.7( \pm 0.3) \mathrm{g} \mathrm{VSS} / \mathrm{m}^{2}$-day compared to $9.3( \pm 0.6)$ and $9.5( \pm 0.5) \mathrm{g} \mathrm{VSS} / \mathrm{m}^{2}$-day for the microalgae. Thus, Oedogonium could serve as a suitable species for biomass production due to its higher productivity rates when compared with microalgal growth.
\end{abstract}

\section{Introduction}

With a large dependence on non-renewable fossil fuels as a source of energy, more sustainable options are being researched to meet society's energy demands without diminishing finite resources. The growth of various species of algae could potentially provide an alternative energy source, in addition to many other environmental benefits. Algae can be used as a feedstock to produce methane gas, a form of bioenergy, through the process of anaerobic digestion where bacteria break down the organic components of algal biomass and release methane as a byproduct (Wilkie, 2008). Arable land is not required for the growth of algae, reducing direct competition with land use for agricultural purposes (Roberts et al., 2013). Algae remove nutrients and toxins from wastewater streams, helping to keep water sources free of contaminants (Cole et al., 2016; Edmundson and Wilkie, 2013; Lincoln et al., 1996; Wilkie and Mulbry, 2002). As part of the process of photosynthesis, algae capture carbon dioxide $\left(\mathrm{CO}_{2}\right)$, a greenhouse gas, from the atmosphere and convert it into their biomass (Lawton et al., 2014). 
In many countries, the combustion of coal at power plants generates the majority of their energy in the form of electricity. This process releases large amounts of $\mathrm{CO}_{2}$ into the atmosphere, contributing to an increase in the earth's warming potential (Singh et al., 2003). To offset the negative impacts of emissions from coal power plants, new ways to capture this carbon are being studied, including the use of algae. Generating bioenergy from algal biomass results in carbon capture that is equivalent to the carbon release once the fuel is burned, creating an overall carbon neutral process (Schamphelaire and Verstraete, 2009). The uptake of carbon directly from the atmosphere by algae is inefficient, but $\mathrm{CO}_{2}$ dissolution in water allows better access to the carbon. Depending upon the $\mathrm{pH}$ of the water, carbon equilibrates between three different forms: $\mathrm{CO}_{2}$ (carbon dioxide), $\mathrm{HCO}_{3}{ }^{-}$(bicarbonate), or $\mathrm{CO}_{3}{ }^{2-}$ (carbonate). $\mathrm{HCO}_{3}{ }^{-}$is the form of carbon most readily available for algal uptake and is at its highest concentration at a $\mathrm{pH}$ of approximately 8 (Choo et al., 2008). Roberts et al. (2013) and Cole et al. (2014) determined that $\mathrm{CO}_{2}$ addition by diffusion in water resulted in an increase in algal biomass productivity. The algal biomass can then be used for multiple applications.

Among the different species of algae being cultivated, Oedogonium, a freshwater filamentous alga, is gaining attention. Typically, cultivation of microalgae has been the most popular choice in recent years for its use in various cosmetic products and in human and animal nutrition (Spolaore et al., 2006). However, filamentous algae are now being researched due to their dominance over other species in most environmental conditions (Lawton et al., 2013). A study based on creating polycultures of the filamentous algae Oedogonium, Cladophora, and Spirogyra and subjecting them to different cultivation conditions to determine a target species for future biomass production demonstrated equal proportions of Oedogonium, Cladophora, and Spirogyra initially. However, after three weeks, the concentration of Oedogonium reached over $80 \%$ in all treatments (Lawton et al., 2013). This revealed the potential for Oedogonium as a superior species for biomass applications in terms of its high productivity and dominance over other filamentous species. Additionally, Oedogonium was shown to be a promising species compared to three strains of filamentous algae where increases in lipid and starch concentrations, which are important properties for biofuel production, were revealed under nitrogen-starved conditions (Zhang et al., 2016). Filamentous algae are also becoming favored in production due to the relative ease of harvesting long thin filaments compared to the small (3-30 $\mu$ m diameter) 
cells of microalgae (Molina Grima et al., 2003; Wilkie et al., 2011). Harvesting filamentous algae could also lead to a reduction in the costs of algal production (Zhang et al., 2016).

The objective of the current study was to assess the harvest productivity and culture density of Oedogonium with the addition of $\mathrm{CO}_{2}$ and compare it to the growth of different polycultures of established microalgae already receiving $\mathrm{CO}_{2}$. This will determine the most suitable species of algae for carbon capture and future biomass production.

\section{Methods}

\section{Algal Inoculation and Culture Condition}

A 1000-L open raceway pond (Pond 2) in Gainesville, Florida was inoculated with a local culture of the filamentous algae, Oedogonium. The pond included a rotating paddle wheel to promote continuous mixing of the algae to enhance sunlight penetration. An additional two 1000-L raceway ponds (Ponds 1 \& 3) with local polycultures of microalgae (Scenedesmus, Dictyosphaerium, Ankistrodesmus, and others) that were already established and receiving $\mathrm{CO}_{2}$ were used as a comparison to the growth of the freshwater alga, Oedogonium. Each pond was supplied with $\mathrm{CO}_{2}$ through diffusion to maintain a set $\mathrm{pH}$ of 8.0 and fertilized with Miracle-Gro (N-P-K: 30-10-10) at a rate of $41.6 \mathrm{~g} /$ week. The $\mathrm{CO}_{2}$ addition was only new to the Oedogonium pond. Temperature and $\mathrm{pH}$ readings were monitored weekly over the course of the four-week study from March 13, 2018 to April 10, 2018. Daily average pond temperatures ranged from $18.1{ }^{\circ} \mathrm{C}$ to $18.3^{\circ} \mathrm{C}$.

\section{Harvesting and Sample Collection}

A 1000-L open raceway pond (Pond 2) in Gainesville, Florida was inoculated with a local culture of the filamentous algae, Oedogonium. The pond included a rotating paddle wheel to promote continuous mixing of the algae to enhance sunlight penetration. An additional two 1000-L raceway ponds (Ponds 1 \& 3) with local polycultures of microalgae (Scenedesmus, Dictyosphaerium, Ankistrodesmus, and others) that were already established and receiving $\mathrm{CO}_{2}$ were used as a comparison to the growth of the freshwater alga, Oedogonium. Each pond was supplied with $\mathrm{CO}_{2}$ through diffusion to maintain a set $\mathrm{pH}$ of 8.0 and fertilized with Miracle-Gro (N-P-K: 30-10-10) at a rate of $41.6 \mathrm{~g} /$ week. The $\mathrm{CO}_{2}$ addition was only new to the Oedogonium pond. Temperature and $\mathrm{pH}$ readings were monitored weekly over the course of the four-week 
study from March 13, 2018 to April 10, 2018. Daily average pond temperatures ranged from $18.1{ }^{\circ} \mathrm{C}$ to $18.3^{\circ} \mathrm{C}$.

\section{Microscopic Analysis of Cultures}

Photomicrographs of the algae were taken at 100x, 250x, and 400x using brightfield microscopy. The images were analyzed on a weekly basis to determine the species makeup and changes in morphotype.

\section{Results}

\section{Culture Density/Growth}

Changes in culture density were determined from the sampled data on a weekly basis to analyze culture growth. An increase in culture density was revealed across all ponds (Table 1). Initially, the established microalgal ponds had higher increases in culture density than the Oedogonium pond. During week 3 of the experiment, Oedogonium had the highest increase in culture density, $382.0( \pm 8.0) \mathrm{mg}$ VSS/L compared to the microalgae with $265.3( \pm 18.0)$ and $260.0( \pm 13.9) \mathrm{mg}$ VSS/L for Ponds 1 and 3, respectively.

Table 1. Weekly algal culture growth

\begin{tabular}{lccc}
\hline & $\begin{array}{c}\text { Microalgae } \\
\text { Pond 1 } \\
(\mathrm{mg} \mathrm{VSS} / \mathrm{L})\end{array}$ & $\begin{array}{c}\text { Oedogonium } \\
\text { Pond 2 } \\
(\mathrm{mg} \mathrm{VSS} / \mathrm{L})\end{array}$ & $\begin{array}{c}\text { Microalgae } \\
\text { Pond 3 } \\
(\mathrm{mg} \mathrm{VSS} / \mathrm{L})\end{array}$ \\
\hline Week 1 & $64.8 \pm 3.9$ & $14.4 \pm 3.9$ & $66.2 \pm 12.0$ \\
Week 2 & $202.6 \pm 8.3$ & $130.0 \pm 7.2$ & $213.3 \pm 2.3$ \\
Week 3 & $265.3 \pm 18.0$ & $382.0 \pm 8.0$ & $260.0 \pm 13.9$ \\
Week 4 & $141.1 \pm 17.4$ & $248.2 \pm 12.6$ & $175.4 \pm 6.2$ \\
\hline Data are means \pm standard deviation $(\mathrm{n}=3)$. &
\end{tabular}

\section{Harvest}

\section{Productivity}

Over the course of the four-week experiment, Oedogonium in Pond 2 surpassed the harvest productivity of microalgae in both Ponds 1 and 3 (Figure 1). Initially, Oedogonium had a lower productivity at $0.6( \pm 0.1) \mathrm{g} \mathrm{VSS} / \mathrm{m}^{2}$-day during week 1 and $4.6( \pm 0.3) \mathrm{g} \mathrm{VSS} / \mathrm{m}^{2}$-day during week 2 , but increased to $13.7( \pm 0.3) \mathrm{g} \mathrm{VSS} / \mathrm{m}^{2}$-day by week 3 and $9.1( \pm 0.3) \mathrm{g} \mathrm{VSS} / \mathrm{m}^{2}$-day by the final week. Microalgae in Ponds 1 and 3 had harvest productivities of $2.3( \pm 0.1)$ and $2.3( \pm$ 0.4) g VSS $/ \mathrm{m}^{2}$-day during week $1,7.4( \pm 0.3)$ and $7.7( \pm 0.1) \mathrm{g} \mathrm{VSS} / \mathrm{m}^{2}$-day during week $2,9.3$ 
$( \pm 0.6)$ and $9.5( \pm 0.5) \mathrm{g} \mathrm{VSS} / \mathrm{m}^{2}$-day during week 3 , and $5.2( \pm 0.6)$ and $6.4( \pm 0.2) \mathrm{g} \mathrm{VSS} / \mathrm{m}^{2}-$ day by the final week, respectively.

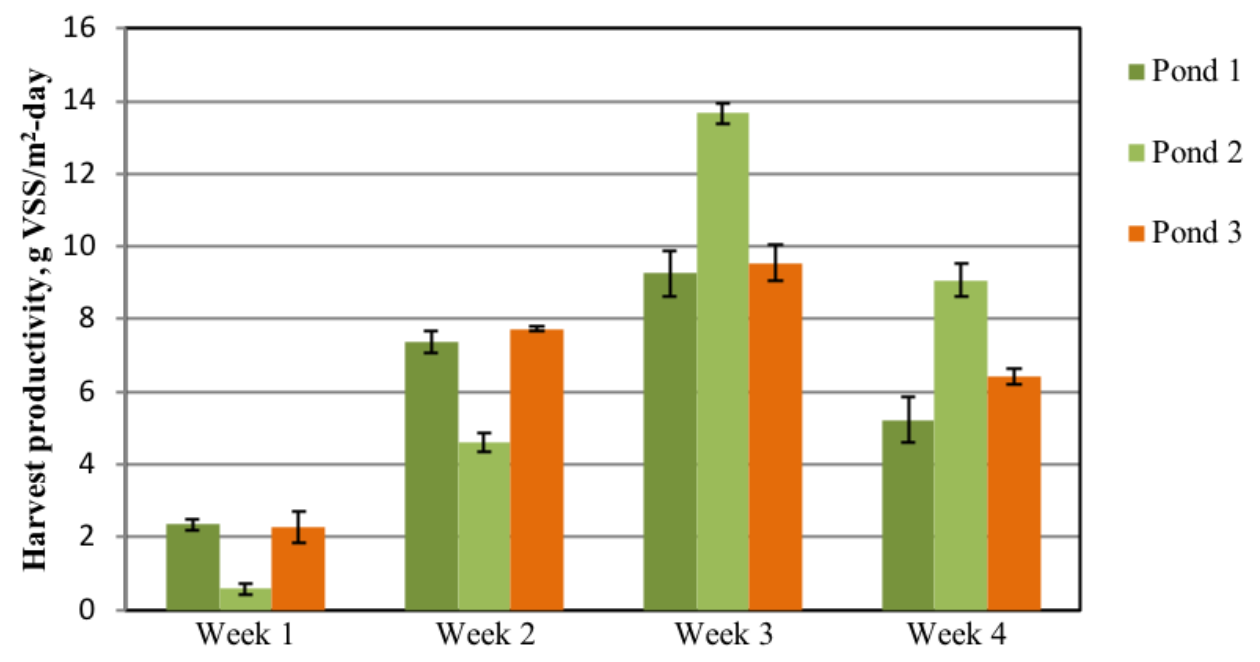

Figure 1. Harvest productivity of Oedogonium (Pond 2) and microalgae (Ponds 1 and 3). Data are means \pm standard deviation $(n=3)$.

\section{Microscopic Analysis}

During the first week, Oedogonium filaments were a dull green color with cell components aggregated towards the center, away from the cell walls (Figure 2). After three weeks, cell components dispersed, filling the entire capacity of the cell wall (Figure 3). The filaments appeared more robust with a brighter green color. Dictyosphaerium was still the dominant microalgae over Scenedesmus in Pond 1 after 3 weeks (Figures 4 and 5). Microalgae in Pond 3 transitioned from a balanced culture of Scenedesmus and Ankistrodesmus in week 3 to a culture dominated primarily by Ankistrodesmus during the final week (Figures 6 and 7).

\section{Discussion}

In terms of harvest productivity and culture growth, Oedogonium outperformed both microalgal ponds. Initially, Oedogonium had the lowest growth and a lower productivity for both week 1 and week 2. By week 3, there was a large increase in growth and productivity for the culture. This was likely due to the time required for the culture to adapt to the addition of $\mathrm{CO}_{2}$. 

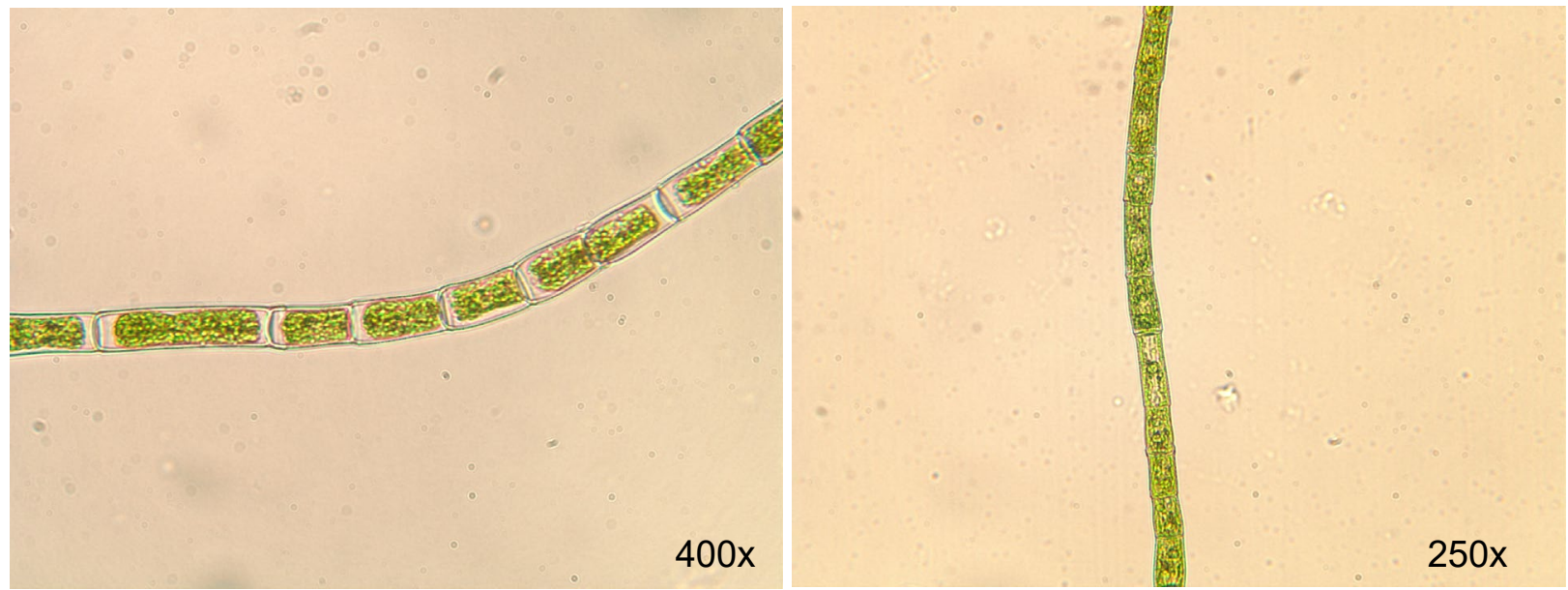

Figure 2. Oedogonium during week 1.

Figure 3. Oedogonium during week 3.
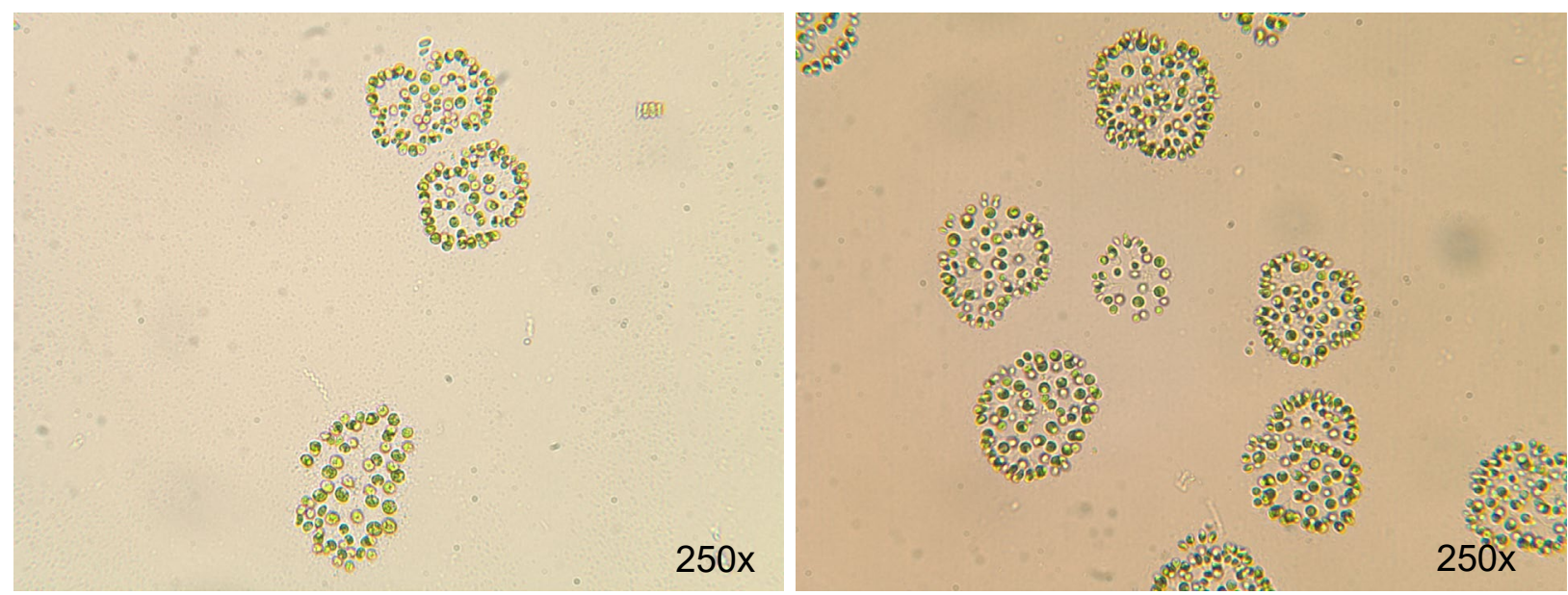

Figure 4. Pond 1 Dictyosphaerium and Scenedesmus, week 1 .

Figure 5. Pond 1 Dictyosphaerium during week 3.
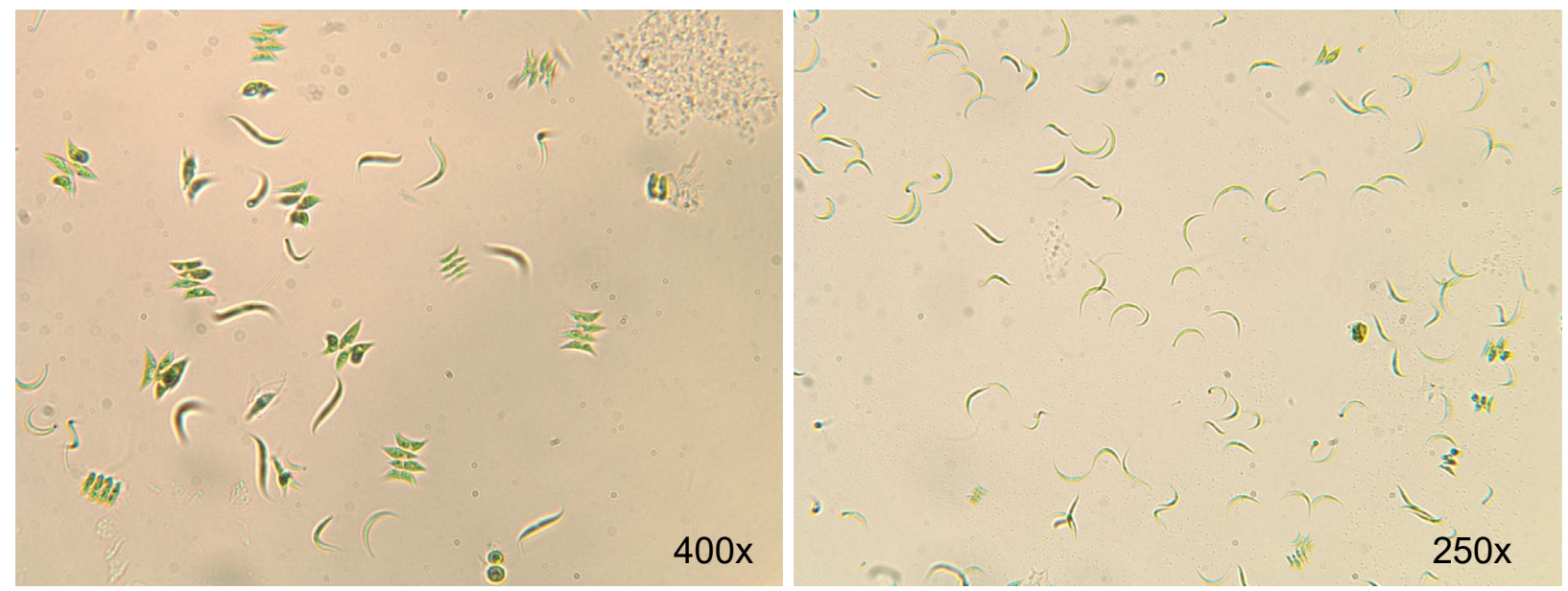

Figure 6. Pond 3 Scenedesmus and Ankistrodesmus, week 3.

Figure 7. Dominance of Ankistrodesmus in Pond 3, week 4. 
The physical changes of the algae indicate that the $\mathrm{CO}_{2}$ addition promoted more robust and brighter green filaments of Oedogonium. These findings reveal the suitability of Oedogonium for future production.

Culture growth and productivity during week 4 likely decreased for all ponds because of a storm that brought 4.9 inches of rain, causing the ponds to overflow and spill some of the biomass. Solar irradiance data received from Florida Automated Weather Network (2018) revealed a significant decrease in irradiance from a high of $252.78 \mathrm{~W} / \mathrm{m}^{2}$ at the beginning of week 4 to a low of $21.65 \mathrm{~W} / \mathrm{m}^{2}$ by the end of the week (Figure 8). Because algae require sunlight for photosynthesis, their productivities likely decreased as a result of lower solar irradiance during week 4.

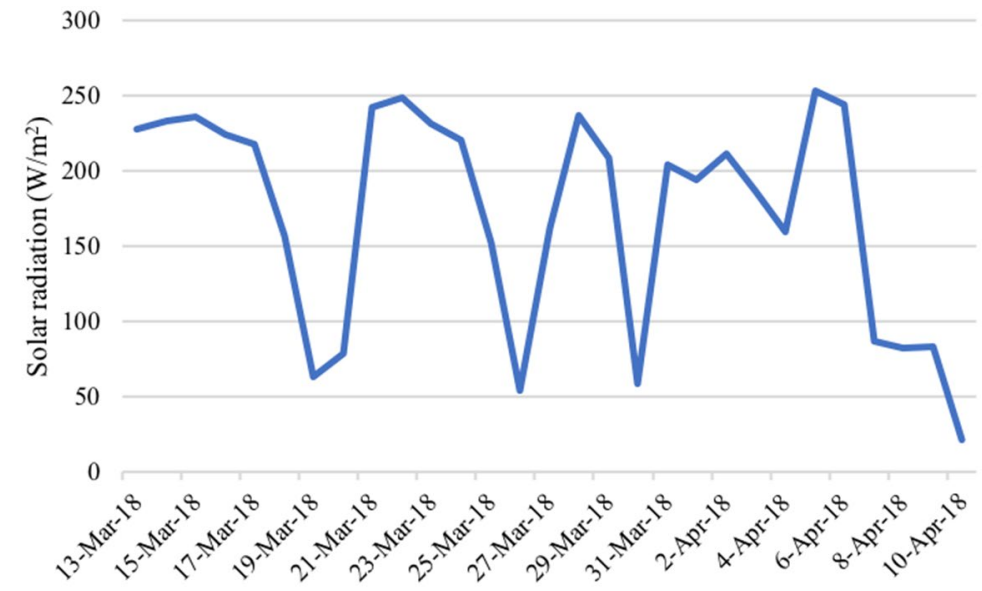

Figure 8. Solar irradiance $\left(\mathrm{W} / \mathrm{m}^{2}\right)$ in Alachua County from Florida Automated Weather Network (2018).

In a study by Cole et al. (2014), biomass productivities of Oedogonium in 15,000 L open outdoor tanks using dechlorinated tap water enriched with Guillards f/2 growth media reached $8.33( \pm 0.51)$ g DW (dry weight) $\mathrm{m}^{-2}$-day when adding $\mathrm{CO}_{2}$ to maintain a $\mathrm{pH}$ of 7.5 . Average culture temperatures during the Australian winter ranged from $18.4{ }^{\circ} \mathrm{C}( \pm 2.2)$ to $19.1^{\circ} \mathrm{C}( \pm$ 2.24). At a latitude of $19.33^{\circ} \mathrm{S}$ in Australia, daily average solar irradiance varies between 173.6 $\mathrm{W} / \mathrm{m}^{2}$ and $231.5 \mathrm{~W} / \mathrm{m}^{2}$ in the winter (Cole et al., 2018). By comparison, the greatest harvest productivity was slightly higher in this study at $13.7( \pm 0.3) \mathrm{g} \mathrm{VSS} / \mathrm{m}^{2}$-day, but both studies reveal high productivities of Oedogonium with $\mathrm{CO}_{2}$ supplementation. In the current study, daily average culture temperatures ranged from $18.1^{\circ} \mathrm{C}$ to $18.3{ }^{\circ} \mathrm{C}$ between ponds, which are similar to the temperatures in the Cole et al. (2014) study. Solar irradiance was also similar in the current 
study. Optimal temperature and solar irradiance conditions for the growth of Oedogonium were identified to be between 20 and $35^{\circ} \mathrm{C}$ and greater than $173.6 \mathrm{~W} / \mathrm{m}^{2}$ (Cole et al., 2018). Thus, harvest productivity of Oedogonium might be even higher during summer months when temperatures are higher.

\section{Conclusion}

Overall, Oedogonium appears to be a suitable species to use for biomass production purposes. Not only did it outperform other genera, the filaments can be harvested easily with a net, and it appears to be quick at adapting to culture conditions to obtain high biomass productivities, demonstrated by its large increase in culture growth during week 2 and week 3. Microalgae may require more cost-intensive production and should be further researched in comparison to different species of filamentous algae. This research suggests Oedogonium is an efficient organism for carbon capture and can potentially be used for multiple sustainable practices, including nutrient removal from wastewaters and bioenergy production in the future.

\section{Acknowledgements}

This research was conducted as part of the 2017-18 CALS University Scholars Program and SWS 4911: Supervised Research in Soil and Water Sciences, at the Bioenergy and Sustainable Technology Laboratory, Soil and Water Sciences Department, UF/IFAS. Funding support was provided by USDOE Project: Microalgae Commodities from Coal Plant Flue $\mathrm{Gas}_{2}$, in collaboration with the Orlando Utilities Commission (OUC), Orlando, Florida.

\section{References}

APHA (2012). Standard Methods for the Examination of Water and Wastewater, $22^{\text {nd }}$ ed. American Public Health Association/American Water Works Association/Water Environment Federation, Washington, DC.

Choo, K., Snoeijs, P. and Pedersen, M. (2008). Uptake of inorganic carbon by Cladophora glomerata (Chlorophyta) from the Baltic Sea. Journal of Phycology, 38(3), 493-502. doi: 10.1046/j.1529$\underline{8817.2002 .01083 . \mathrm{x}}$

Cole, A., Praeger, C., Mannering, T., de Nys, R. and Magnusson, M. (2018). Hot and bright: Thermal and light environments for the culture of Oedogonium intermedium and the geographical limits for large-scale cultivation in Australia. Algal Research, 34, 209-216. doi:10.1016/j.algal.2018.08.004

Cole, A.J., Mata, L., Paul, N.A. and de Nys, R. (2014). Using $\mathrm{CO}_{2}$ to enhance carbon capture and biomass applications of freshwater macroalgae. GCB Bioenergy, 6(6), 637-645. doi: 10.1111/gcbb.12097 
Cole, A. J., Neveux, N., Whelan, A., Morton, J., Vis, M., de Nys, R. and Paul, N. A. (2016). Adding value to the treatment of municipal wastewater through the intensive production of freshwater macroalgae. Algal Research, 20(Supplement C), 100-109. doi: 10.1016/j.algal.2016.09.026

Edmundson, S.J and Wilkie, A.C. (2013). Landfill leachate - a water and nutrient resource for algae-based biofuels. Environmental Technology, 34(13-14), 1849-1857. doi: 10.1080/09593330.2013.826256

Florida Automated Weather Network (2018). Retrieved April 16, 2018, from http://fawn.ifas.ufl.edu/data/reports/

Lawton, R.J., de Nys, R. and Paul, N.A. (2013). Selecting reliable and robust freshwater macroalgae for biomass applications. PLOS ONE, 8(5), e64168. doi: 10.1371/journal.pone.0064168

Lawton, R.J., de Nys, R., Skinner, S. and Paul, N.A. (2014). Isolation and identification of Oedogonium species and strains for biomass applications. PLoS ONE, 9(3), e90223. doi: 10.1371/journal.pone.0090223

Lincoln, E.P., Wilkie, A.C. and French, B.T. (1996). Cyanobacterial process for renovating dairy wastewater. Biomass and Bioenergy, 10(1), 63-68. doi: 10.1016/0961-9534(95)00055-0

Molina Grima, E., Belarbi, E.H., Acién Fernández, F.G., Robles Medina, A. and Chisti, Y. (2003). Recovery of microalgal biomass and metabolites: process options and economics. Biotechnology Advances, 20(7-8), 491-515. doi:10.1016/S0734-9750(02)00050-2

Roberts, D.A., de Nys, R. and Paul, N.A. (2013). The effect of $\mathrm{CO}_{2}$ on algal growth in industrial waste water for bioenergy and bioremediation applications. PLOS ONE, 8(11), e81631. doi: 10.1371/journal.pone.0081631

Schamphelaire, L.D. and Verstraete, W. (2009). Revival of the biological sunlight-to-biogas energy conversion system. Biotechnology and Bioengineering, 103 2, 296-304. doi: $\underline{\text { 10.1002/bit.22257 }}$

Singh, D., Croiset, E., Douglas, P.L. and Douglas, M.A. (2003). Techno-economic study of $\mathrm{CO}_{2}$ capture from an existing coal- fired power plant: MEA scrubbing vs. $\mathrm{O}_{2} / \mathrm{CO}_{2}$ recycle combustion. Energy Conversion and Management, 44(19), 3073-3091. doi:10.1016/S0196-8904(03)00040-2

Spolaore, P., Joannis-Cassan, C., Duran, E. and Isambert, A. (2006). Commercial applications of microalgae. Journal of Bioscience and Bioengineering, 101(2), 87-96. doi: $10.1263 / \mathrm{jbb} .101 .87$

Wilkie, A.C. (2008). Biomethane from biomass, biowaste, and biofuels. In: Wall J, Harwood C, Demain A (ed), Bioenergy, p.195-205. Washington, DC: ASM Press. doi: $\underline{10.1128 / 9781555815547 . c h 16}$

Wilkie, A.C., Edmundson, S.J. and Duncan, J.G. (2011). Indigenous algae for local bioresource production: Phycoprospecting. Energy for Sustainable Development, 15(4), 365-371. doi: 10.1016/j.esd.2011.07.010

Wilkie, A.C. and Mulbry, W.W. (2002). Recovery of dairy manure nutrients by benthic freshwater algae. Bioresource Technology, 84(1), 81-91. doi: 10.1016/S0960-8524(02)00003-2

Zhang, W., Zhao, Y., Cui, B., Wang, H. and Liu, T. (2016). Evaluation of filamentous green algae as feedstocks for biofuel production. Bioresource Technology, 220, 407-413.

doi:10.1016/j.biortech.2016.08.106 